\title{
DOI: http://dx.doi.org/10.17058/barbaroi.v0i0.6861 \\ INTERVENÇÕES GENÉTICAS EM SERES HUMANOS: ASPECTOS ÉTICOS E JURÍDICOS
}

\author{
Elis Cristina Uhry Lauxen \\ Universidade do Vale do Rio dos Sinos - UNISINOS - Brasil \\ José Roberto Goldim \\ Universidade do Vale do Rio dos Sinos - UNISINOS - Brasil
}

\section{Resumo}

Os avanços da biotecnologia podem gerar crescentes e significativas transformações na vida e na saúde de seres humanos. Em que pese os relevantes benefícios que advêm do uso das respectivas técnicas, os riscos inerentes e o desconhecimento de limites são motivos de inquietações e divergências, especialmente no que diz respeito às intervenções genéticas. Exemplo recente é o uso do sistema CRISPR-Cas9 (Clustered Regularly Interspaced Short Palindromic Repeats - Cas9 associated) para introduzir mutações específicas no genoma humano. O presente artigo tem como escopo abranger aspectos éticos e jurídicos que permeiam a medicina genética corretiva. Para desenvolver o objetivo proposto, utilizamos o método qualitativo de abordagem, mediante pesquisa documental sobre o assunto. Como resultado, apuramos a importância da (des)construção de parâmetros para nortear o desenvolvimento e a implementação das técnicas de intervenção na genética humana, de modo a promover maior segurança à pesquisa e à humanidade.

Palavras-chave: Sistemas CRISPR-Cas. Bioética. Direito.

\section{Introdução}

O mundo, como é notório, passa por constantes transformações. Todavia, nas últimas décadas, as mudanças ocorrem em crescente velocidade, principalmente no que diz respeito ao desenvolvimento tecnocientífico. Na Biomedicina, a aceleração não é a única novidade, porquanto as mutações têm potencial para realizar intervenções nos maiores valores da existência humana: a vida e a saúde.

A Genética, que sempre buscou entender os mecanismos de herança das características dos seres vivos ao longo das gerações, uniu-se à Biologia Molecular e possibilitou a alteração do próprio DNA. Em 1974, foi criada a técnica denominada TALEN (Transcription Activator-Like Effector Nucleases) para realizar a edição do DNA. Nas pesquisas realizadas em bacteriófagos (vírus que atacam bactérias), as enzimas que possibilitaram realizar as 
respectivas mutações foram denominadas de "tesouras genéticas", caracterizando o início da Engenharia Genética.

As repercussões sobre a possibilidade de alterar o próprio código do DNA ao invés de apenas descrevê-lo, associada à pouca precisão do método TALEN, causaram preocupações na comunidade científica, de modo que foi proposta e amplamente acatada uma moratória voluntária das pesquisas, para a discussão do assunto. Em 1975 foi realizado o Congresso Internacional sobre Moléculas de DNA Recombinante, na cidade de Asilomar, Califórnia. A mencionada conferência, na qual participaram cientistas e representantes da sociedade, motivou a elaboração de normas de biossegurança e limites das pesquisas com DNA recombinante.

A busca pelo aperfeiçoamento da edição do DNA levou ao desenvolvimento da técnica ZFN (Zinc Fingers Nucleases). A tecnologia aprimorou o método TALEN e melhorou a precisão da edição de sequências de DNA manipuladas em laboratórios. A nova técnica apenas refinou o procedimento existente, de modo que não gerou maiores repercussões éticas, nem tampouco alterações nas regras de biossegurança.

Sobreveio o método CRISPR (Clustered Regularly Interspaced Short Palindromic Repeats), uma técnica relativamente simples e precisa em termos de sequências editadas. Devido às características de maior precisão, as antigas "tesouras genéticas" passaram a ser denominadas de "bisturis genéticos". Para realizar mutações específicas, inicialmente foi produzida uma proteína diferente para cada genoma a ser modificado. Posteriormente, a técnica foi associada à proteína 9, que resultou no sistema denominado CRISPR-Cas9, passando a utilizar a mesma proteína para os diversos genomas objeto de modificação.

A técnica foi dirigida inicialmente a bacteriófagos e há mais de dez anos é aplicada industrialmente, na produção de iogurtes e queijos, para impedir a deterioração dos respectivos produtos. Após experimentos em camundongos, foram criados macacos geneticamente modificados com o objetivo de diagnosticar e tratar doenças graves em seres humanos. Recentemente, foram divulgadas pesquisas de aplicação do método em embriões humanos para corrigir defeitos genéticos.

As crescentes pesquisas e o interesse pela técnica CRISPR-Cas9 são acompanhados por indagações e preocupações acerca de sua implementação. A sociedade tecnocientífica defronta-se novamente com as perspectivas e os temores diante das possibilidades da "Medicina de Precisão". 
Neste contexto, o presente artigo busca refletir acerca de aspectos éticos e jurídicos que permeiam as intervenções genéticas em seres humanos, especialmente no que diz respeito à implementação do sistema CRISPR-Cas9. Para desenvolver o objetivo proposto, utilizaremos o método qualitativo de abordagem, mediante pesquisa documental, porquanto possibilita desvelar processos ainda pouco conhecidos (MINAYO, 2007). Assim, investigaremos em que medida é indicada a (des)construção de paradigmas e de diretrizes com relação às técnicas de terapia gênica e de melhoramento genético.

\section{O uso do Sistema CRISPR-Cas9 em seres humanos}

O conhecimento humano cria possibilidades que somente foram imaginadas no passado $^{1}$, tornam-se realidade no presente e geram inquietações com relação ao futuro (LAUXEN, 2014). As pesquisas apontam que o sistema CRISPR-Cas9 (Clustered Regularly Interspaced Short Palindromic Repeats - Cas9 associated), que significa "Repetições Palindrômicas Curtas Agrupadas e Regularmente Interespaçadas - associadas à Proteína 9", tem potencial para curar doenças genéticas e até mesmo alterar demais características humanas. Assim, a nova técnica de edição genética promove expectativas diante dos benefícios anunciados e preocupações com relação aos aspectos éticos e riscos que permeiam implementação da técnica.

A técnica foi descoberta como um mecanismo de defesa de determinadas bactérias contra vírus invasores (bacteriófagos), isto é, uma espécie de sistema imunológico. A configuração da sequência de DNA foi chamada de agrupamentos de curtas repetições palindrômicas regularmente interespaçadas - que deu origem à sigla CRISPR. Pesquisas constataram que as sequências únicas entre as repetições combinavam com o DNA de determinados vírus. Assim, a CRISPR constitui uma parte do sistema imunológico bacteriano que mantém determinados vírus ao seu redor para reconhecer e defender-se das ameaças durante os próximos ataques (ZHANG, 2015).

A segunda parte do mecanismo é um conjunto de enzimas chamadas Cas (proteínas associadas à CRISPR), que podem cortar precisamente o DNA e eliminar vírus invasores.

\footnotetext{
${ }^{1}$ Obras de ficção científica retratam nossas inquietações com relação às novas tecnologias, entre as quais podemos destacar o hipotético "Admirável Mundo Novo", de Aldous Huxley, publicado em 1932, que sai do imaginário do autor e torna-se uma perspectiva de futuro diante da realidade biotecnológica do presente. (HUXLEY, 1979).
} 
Existem diversas enzimas Cas, sendo a Cas9 a mais conhecida (que vem da Sreptococcus Pyogenes, bactéria conhecida por causa infecção da garganta). A combinação gerou o sistema CRISPR-Cas9. Assim, Cas9 é uma enzima que corta DNA e CRISPR é uma coleção de sequências de DNA que direcionam onde exatamente a Cas9 deve cortar. Portanto, somente é preciso fornecer a sequência correta à Cas9, chamada de RNA guia, e podem ser cortadas partes de sequências de DNA no genoma conforme o objetivo (ZHANG, 2015) e (NAU, 2014).

A ferramenta, que vem sendo utilizada pela indústria leiteira na cultura de iogurtes e queijos para impedir a contaminação das bactérias por vírus, foi gradativamente aperfeiçoada e passou a ser considerada uma importante solução para evitar o desperdício de alimentos(GRENS, 2015). Sobrevieram experimentos que demonstraram que a técnica também pode agir em plantas, animais e, inclusive, em serem humanos (CRESSEY, 2013).

Pesquisas realizadas com o uso do método em camundongos demonstraram o potencial de cura de doenças que ocorrem em seres humanos (YIN, et. al., 2014). Posteriormente, cientistas chineses alteraram, com sucesso, sequências específicas de DNA em macacos, possibilitando a geração de macados com doenças humanas, tais como Alzheimer e Parkinson, para servirem como modelos no diagnóstico e tratamento de doenças graves em seres humanos (NIU, et al., 2014). A reação inicial, favorável às pesquisas, passou a indagar a adequação em espécies com tão alto grau de desenvolvimento. Os maiores questionamentos referem-se ao direito de gerar intencionalmente linhagens de animais portadores de doenças tão graves, assim como à possibilidade de patenteamento das respectivas linhagens e a consequente apropriação do patrimônio genético por companhias ou pessoas.

Em abril de 2015, foi publicado o resultado de nova pesquisa realizada na China, que utilizou o mecanismo CRISPR-Cas9 para a edição de sequências de DNA em embriões humanos. A pesquisa envolveu 86 embriões produzidos para fins de reprodução assistida, considerados inviáveis por terem 3 conjuntos de 23 cromossomos, ao invés de 2 , como seria o normal. $\mathrm{O}$ objetivo dos cientistas foi a substituição de um gene cuja mutação está associada à doença Beta-Talassemia. Dos 86 embriões utilizados na pesquisa, 71 (82,6\%) sobreviveram ao procedimento inicial de edição do DNA. No final do experimento, apenas 7 embriões apresentaram a recombinação desejada. Foram verificadas, também, outras substituições de sequências não desejadas, que poderiam acarretar mutações inesperadas. Os autores sugeriram 
que mais pesquisas seriam necessárias para verificar a viabilidade de aplicação do método utilizando embriões normais (LIANG; et al., 2015).

Em setembro de 2015, uma cientista britânica solicitou autorização para pesquisar a utilização do sistema em embriões humanos excedentes, visando investigar o grau de eficiência do método de CRISPR-Cas9, sem envolver sequências associadas a doenças. A finalidade aventada é conhecer melhor o desenvolvimento embrionário inicial e o potencial de aplicação da técnica para pesquisas com células-tronco. A solicitação foi encaminhada ao órgão governamental britânico responsável pela pesquisa envolvendo embriões: Human Fertilisation and Embryology Authority - HFEA. (CRESSEY; ABBOTT; LEDFORD, 2015).

O interesse pelo sistema CRISPR-Cas9, especialmente no campo da genética humana, é crescente. As pesquisas brasileiras, conforme veremos adiante, não enfrentam barreiras regulatórias. Podemos apontar como exemplos: a pesquisa desenvolvida na UFRGS sobre "O uso do sistema CRISPR-Cas9 para correção de mutações em erros inatos do metabolismo" (BALDO, 2015), as investigações da PUCRS sobre o "Sistema de edição genômica CRISPRCas9 em zebrasfish para desenvolvimento de modelos complementares da Doença de Alzheimer" (RESULTADO FINAL PROBITI/FAPERGS, 2015), o fomento da FAPESP a experimentos com a aplicação do mecanismo em animais e seres humanos em busca da cura de doenças, que na fonte referencial de informação para a pesquisa neste âmbito indica 23 projetos cadastrados (BIBLIOTECA VIRTUAL FAPESP, 2015).

O desenvolvimento da tecnologia CRISPR-Cas9 vem trazendo perspectivas de cura de doenças e representa o protótipo de terapia genética. Diferentes estratégias biológicas para a engenharia genômica têm aparecido, mas a maioria revela limitações relacionadas à baixa eficiência, manutenção ou riscos significativos. O mecanismo apresenta uma maneira muito mais simples e segura para a modificação do gene alvo. Vários estudos em células e modelos animais tem sido publicados, demonstrando suas vantagens com relação às técnicas de terapia gênica convencionais. Estudos crescentes vem sendo realizados para o tratamento de determinados grupos de doenças genéticas (CARVALHO; et al., 2015).

O mecanismo CRISPR-Cas9 possibilita mutações distintas em genomas de qualquer espécie, com precisão, eficiência e baixo custo, entretanto, ainda não temos conhecimento exato das implicações do uso da mencionada ferramenta (BALDO, 2015) e nem tampouco quem poderá fazer uso da tecnologia. A utilização da técnica diante da necessidade de novas terapias e as limitações das opções disponíveis tem comprovado potencial de eficácia no 
tratamento de doenças genéticas, entretanto, em razão de tratar-se de recente mecanismo, deverão ser observados os aspectos relacionados aos benefícios e riscos que permeiam a aplicação da técnica. (CARVALHO; et al., 2015). Em suma, o sistema representa perspectivas promissoras para a terapia gênica e o aperfeiçoamento genético, contudo, é preciso cuidado em razão da nossa (in)capacidade de controlar os respectivos resultados e dos interesses que poderão advir de sua implementação.

Quando uma nova tecnologia é introduzida e aplicada à pesquisa genética, são necessárias reflexões acerca de sua utilização, na medida em que uma das principais questões é a irreversibilidade das respectivas ações (GOLDIM, 2015). A medicina genética corretiva se depara com amplas possibilidades de aperfeiçoamento da genética humana e, ao mesmo tempo, com perigos reputados possíveis e que, no entanto, não foram ainda empiricamente constatados (HONNEFELDER, 2003).

Os valores também são motivo de preocupações, mesmo quando estivermos mais seguros do nosso controle técnico, será preciso refletir em que medida poderemos avançar e se dispomos de recursos para utilizar os avanços na área da genética com prudência e humanidade (BUCHANAN, et al., 2000).

O sistema CRISPR-Cas9 traz potenciais avanços em benefício da vida e da saúde humana, restando evidente a importância do uso da técnica em seres humanos. Contudo, não podem ser olvidados os riscos desconhecidos e os inerentes ao uso da técnica. Portanto, a análise das questões éticas e jurídicas que permeiam a aplicação do mecanismo para realizar intervenções genéticas em seres humanos é, sem dúvida, um dos grandes e prementes desafios atuais.

\section{A polêmica do aperfeiçoamento genético e o temor da eugenia}

As técnicas de intervenção na genética humana representam uma promessa e um dilema. A promessa é a oportunidade de prevenir e tratar doenças e o dilema, além dos riscos, é a possibilidade de manipular a natureza humana para escolher o sexo, definir características físicas, tais como melhoramento muscular, aumento da memória, alteração da estatura, etc. (SANDEL, 2013). A distinção entre curar e melhorar, contudo, é uma linha tênue e polêmica no campo do aperfeiçoamento genético.

Relevado que os avanços da engenharia genética constantemente desembocam nos 
temores da eugenia (BUCHANAN; et al., 2000), é importante observar os aspectos que diferenciam a eugenia que no século passado causou atrocidades até hoje não esquecidas, da eugenia relacionada aos atuais avanços da engenharia genética. Enquanto aquela abrangeu uma coletividade, esta conduz a escolhas individuais, sendo menos rigorosa e idealista do que aquela, que nasceu da aspiração de aprimorar a humanidade ou promover o bem-estar coletivo de sociedades inteiras (SANDEL, 2013).

Todavia, em que pese a eugenia liberal tenha como objeto o indivíduo e não a coletividade e, a princípio, seja caracterizada pela neutralidade do Estado, também poderá implicar compulsoriedade estatal. Segundo os defensores do melhoramento genético não há diferença do ponto de vista moral entre melhorar as capacidades intelectuais de uma criança por meio da educação ou mediante intervenção genética. Considerando que é papel dos pais promover o bem-estar dos filhos, os melhoramentos poderão tornar-se não somente aceitáveis, mas obrigatórios, de modo que o Estado pode determinar que os pais mandem os filhos para a escola ou que utilizem as técnicas de intervenção genética para aumentar a capacidade intelectual. Nesta linha de raciocínio, o que importa é que a educação ou a intervenção genética não violem a autonomia da criança, isto é, desde que as habilidades melhoradas sejam um meio válido para todos os fins e não direcionem a criança para nenhuma carreira ou modo de vida específicos (SANDEL, 2013).

No âmbito de tais discussões, Jürgen Habermas (2004) defende que é preciso estabelecer uma linha de fronteira entre eugenia negativa e eugenia positiva, ao contrário da margem de tolerância da eugenia liberal. A primeira, refere-se às intervenções genéticas de caráter terapêutico, para prevenir doenças hereditárias graves e outras enfermidades, a segunda, está relacionada às intervenções genéticas de aperfeiçoamento das características do ser humano. Por sua vez, a eugenia liberal, segundo o mencionado filósofo, não reconhece um limite entre as intervenções terapêuticas e de aperfeiçoamento, deixando à preferência individual as ingerências na genética. Neste contexto, Habermas apresenta críticas às técnicas de aperfeiçoamento genético e manifesta-se favoravelmente à prática eugênica com objetivos terapêuticos.

Os avanços da genética, segundo Habermas (2004), conduzem cada vez mais o que somos "por natureza" ao campo das intervenções biotecnológicas, que poderão decidir o futuro da evolução biológica da espécie humana, caracterizando uma ameaça à autonomia, à dignidade e à natureza humana. $\mathrm{O}$ aperfeiçoamento genético, nesta ótica, tem potencial para 
sermos fabricados e transformados em máquinas projetadas para alto rendimento e objeto de interesses econômicos, políticos, militares, etc.

De encontro ao entendimento habermasiano, Buchanan, Brock, Daniels e Wikler (2000) defendem que o melhoramento genético é moralmente justificável, porquanto expressa a essência criativa e autodeterminadora do ser humano. A inteligência humana, segundo os autores de "From Chance to Choice: Genetics and Justice", também precisa ser aprimorada para acompanhar a velocidade e a complexidade dos avanços tecnológicos, do contrário, poderemos ser transformados em reféns da tecnologia. Acrescentam, ainda, que a nossa natureza depende do ambiente em que estamos inseridos, isto é, há uma correspondência entre os genes e o ambiente, contrariando a concepção essencialista e fixista da natureza humana, em prol de uma concepção adaptativa correspondente à biologia evolutiva. Sob esta ótica, a existência humana se expressa pela capacidade inata de modificar-se de acordo com o ambiente e não por manter-se inalterada.

Nesta perspectiva, Andorno (2009) salienta que a liberdade é uma das faculdades que caracteriza o ser humano e permeia sua dignidade, de modo que a liberdade científica e a dignidade humana podem (e devem) relacionar-se de modo harmônico. Enquanto os demais seres vivos estão condicionados pelo instinto, o ser humano, mediante o uso da razão, tem a liberdade para escolher a conduta a seguir. Entretanto, ao mesmo tempo em que podemos permitir a implementação de novas biotecnologias, também precisamos estabelecer limites para que as intervenções genéticas não ocorram em detrimento do próprio ser humano.

A propósito, Frederick Schauer (1985), ao propor o conceito de "Slippery Slope", traduzido como "lomba escorregadia", alerta no sentido de que um ato isolado, aparentemente inocente, pode levar a futuros eventos de crescente malefício. Nesta linha de raciocínio, não há como olvidar que as pesquisas até agora consideradas como fatos isolados, no futuro poderão gerar crescentes malefícios se não forem adotadas providências no sentido de criar parâmetros para o desenvolvimento e implementação das respectivas tecnologias.

Ademais, o "analfabetismo científico", destacado por Julian Savulescu (2010), favorece a realização de pesquisas com potencial de riscos iminentes ou desconhecidos, sem que recebam destaque e a análise necessários. Neste âmbito, é importante ressaltar a perspectiva kantiana de não instrumentalização da pessoa humana, isto é, no sentido de não se pode utilizar pessoas apenas como meio, destituindo-as de sua dignidade (KANT, 2009). 
Mediante tal pressuposto, é possível construir limites éticos e jurídicos às intervenções da biotecnologia no ser humano (ANDORNO, 2009).

Ao discorrer sobre a manipulação genética, Hans Jonas (2006) acentua que o ser humano busca controlar a própria evolução, não somente para conservar a espécie em sua integridade, mas para melhorá-la e modificá-la de acordo com o seu próprio projeto. Saber se o ser humano tem o direito e é qualificado para esse papel criador é a pergunta mais séria que se pode fazer àquele que se encontra na posse desse poder tão grande diante do destino. A pergunta exige uma resposta antes que o ser humano se deixe levar em uma viagem ao desconhecido.

Em suma, passamos a viver uma nova era, em que nossos conhecimentos sobre a vida humana tornam-se cada vez maiores e exercemos um controle sem precedentes sobre todos os seres vivos, incluindo nós mesmos. O conhecimento científico poderá prevenir e curar enfermidades, assim como modelar características biológicas dos seres humanos. Ainda não conhecemos os limites da nossa capacidade de modelar vidas humanas, nem tampouco quando serão alcançados e quais os interesses poderão estar envolvidos. Portanto, sejam quais forem as novas possibilidade técnicas, enfrentar este poder colocará à prova a nossa sabedoria (BUCHANAN; et al., 2000) e responsabilidade.

\section{O papel do Estado no âmbito das intervenções genéticas}

A saúde é condição fundamental da vida humana. Neste âmbito, conforme preconiza Amartya Sen (2010), é preciso observar que a equidade na saúde é multidimensional, isto é, a saúde entra no contexto da justiça social de várias formas distintas e que não produzem exatamente a mesma leitura de específicos arranjos sociais. Qualquer justiça social que aceite uma distribuição equitativa e uma exploração eficiente das capacidades humanas não pode ignorar a importância da saúde na vida humana e as oportunidades das pessoas obterem uma vida saudável, sem doenças, sofrimentos evitáveis ou mortalidade prematura.

No que diz respeito à medicina genética corretiva, as intervenções genéticas podem ser contempladas precipuamente sob duas perspectivas: como um modelo de saúde pública ou como um modelo de eleição pessoal. O primeiro, tem como objeto produzir benefícios e sobrestar danos a determinados grupos ou à coletividade, tendo como parâmetro o custobenefício, de natureza utilitarista, de modo que para uma ação ou uma política serem 
consideradas corretas os resultados bons devem superar os maus. Assim, os cálculos custobenefício e custo-efetividade consideram a inclusão obrigatória de diferentes indivíduos, de modo que os danos causados a alguns podem ser compensados com os benefícios obtidos por outros, ou seja, o que importa é a soma. O segundo, afasta-se do domínio público e é introduzido na esfera da eleição privada, tendo como valor fundamental a autonomia individual, de modo que as intervenções genéticas são caracterizadas como serviços oferecidos aos indivíduos, isto é, bens de consumo privado, que podem ser aceitos ou recusados conforme cada um considerar adequado (BUCHANAN; et al., 2000).

Os avanços no campo da engenharia genética, conforme observa Adela Cortina (2009), despertam receio nos setores sociais mais bem informados, na medida em que se trata de um conjunto de conhecimentos que pode colocar nas mãos de determinadas pessoas o poder de decidir o futuro da evolução biológica da espécie humana. As técnicas desenvolvidas permitem aplicações que podem ser consideradas benéficas em determinados aspectos, entretanto, também favorecem ingerências discutíveis, como a possibilidade de "criar" novos tipos de seres humanos a partir de modificações genéticas.

É preciso observar ainda, que a sociedade é movida por dinâmicas políticas e econômicas que muitas vezes se sobrepõem à dignidade humana, de acordo com os interesses envolvidos. Não obstante a tendência no sentido de considerar o ser humano o centro da tutela do Estado, o corpo, a vida e o viver tornou-se centro de interesse do poder. O chamado biopoder promove uma espécie de gestão da vida da população, que se torna cada vez mais abrangente mediante as dinâmicas da biopolítica, que podem utilizar as novas tecnologias como ferramenta. Em suma, o antigo poder que "fazia morrer e deixava viver" foi modificado pela tecnologia do biopoder para "fazer viver e deixar morrer" (FOUCAULT, 2002) e, mais recentemente, até mesmo em "adiar o fazer viver e o deixar morrer." (GOLDIM, 2014).

O mencionado poder, inicialmente exercido pelo Estado, passou a ser exercido também pelo segmento que detém o controle das biotecnologias. Assim, se antes o biopoder manifestava-se como gestão do Estado, da vida biológica dos corpos e das populações, atualmente revela-se como agenciamento das técnicas a serviço da saúde por parte das empresas biotecnológicas. Em ambos os casos encontra-se presente o controle, no primeiro, mais direto e numa perspectiva biológica e no segundo, mais sutil, de cunho consumista e simbólico (JUNGES, 2011). 
Portanto, é preciso que sejam adotadas providências no sentido de criar diretrizes para nortear o desenvolvimento e a implementação de tecnologias de intervenção na vida e na saúde humana. Como bem salienta Giorgio Resta, as ações decorrentes do desenvolvimento biotecnológico implicam a redefinição dos limites do poder do ser humano sobre ele mesmo e sobre o ambiente que o cerca (RESTA, 2009).

As descobertas científicas e as novas tecnologias renovam o debate iniciado com a Declaração Universal dos Direitos Humanos. A discussão é retomada nas Cortes Regionais de Direitos Humanos, Conferências, Comitês de Ética, acordos culturais, que assumem grande importância, levando cada cultura ao aprofundamento das questões em busca de respostas compatíveis com seus referenciais (DELMAS-MARTY, 2009).

A Conferência de Asilomar, realizada na Califórnia, em 1975, oriunda da proposta de moratória nas pesquisas que envolvessem manipulação genética, é um relevante exemplo. Um grupo de pesquisadores, entre os quais, Paul Berg, David Baltimore e James Watson (Prêmio Nobel em 1962), encaminharam uma carta às revistas Science, Nature e Proceedings of National Academy of Sciences, que foi publicada em julho de 1974, alertando acerca de potenciais riscos da técnica de edição do DNA chamada TALEN. Também foi proposta e amplamente acatada uma moratória voluntária das pesquisas, para a discussão do assunto entre os cientistas e a sociedade. Em 1975 foi realizado o Congresso Internacional sobre Moléculas de DNA Recombinante, na cidade de Asilomar, Califórnia. Como resultado, o Comitê elaborou um documento, indicando diretrizes para a segurança dos experimentos com DNA recombinante, visando o controle e a minimização dos riscos do desenvolvimento científico. No ano seguinte, em 1976, o governo norte-americano estabeleceu normas para a pesquisa com DNA recombinante baseadas no documento de Asilomar (GOLDIM, 2015).

Sobrevieram documentos como a Convenção sobre os Direitos do Homem e a Biomedicina, do Conselho da Europa em Oviedo, em 4 de abril de 1997, o Protocolo Adicional, que proíbe a Clonagem de Seres Humanos, aberto à assinatura dos Estadosmembros em Paris, em 12 de janeiro de 1998 e a Declaração Universal sobre Bioética e Direitos Humanos, da UNESCO, adotada em 19 de outubro de 2005, na Sessão da Conferência Geral da UNESCO em Paris, a casuística das Cortes Internacionais (DELMASMARTY, 2009). 
Os Estados também passaram a adotar posturas regulatórias com relação aos avanços científicos, mormente no que diz respeito às intervenções genéticas em seres humanos, como bem ilustra a tabela abaixo:

Tabela. Políticas sobre a modificação genética da linhagem germinativa humana para a reprodução excluindo a clonagem reprodutiva

\begin{tabular}{|c|c|c|c|}
\hline Jurisdição & $\begin{array}{l}\text { Postura } \\
\text { regulatória com } \\
\text { relação à } \\
\text { modificação } \\
\text { genética da } \\
\text { linhagem } \\
\text { germinativa }\end{array}$ & $\begin{array}{l}\text { Legislação ou diretrizes } \\
\text { relevantes }\end{array}$ & Observações \\
\hline África do Sul & Ambígua & $\begin{array}{l}\text { Lei da saúde nacional (2003, } \\
\text { alterada em 2013) }\end{array}$ & $\begin{array}{l}\text { Embora a clonagem reprodutiva seja proibida, a } \\
\text { legalidade de outras formas de modificação } \\
\text { genética da linhagem germinativa não é clara na } \\
\text { lei. }\end{array}$ \\
\hline Alemanha & proibitiva & Lei de proteção ao embrião (1990) & $\begin{array}{l}\text { Alterar artificialmente a informação genética de } \\
\text { um gameta humano e usar um gameta humano com } \\
\text { informação genética artificialmente alterada para } \\
\text { fertilização, são proibidos. }\end{array}$ \\
\hline Argentina & ambígua & $\begin{array}{l}\text { Decreto 200/1997: proibição de } \\
\text { experimentos de clonagem humana }\end{array}$ & $\begin{array}{l}\text { Embora não exista uma lei que regule as } \\
\text { tecnologias de reprodução assistida (Hevia and } \\
\text { Vacaflor. 2013. Suffork Transnational Law Rev. } \\
\text { 36, p60), a posição sobre a modificação genética da } \\
\text { linhagem germinativa (excluída a clonagem } \\
\text { reprodutiva) é ambígua no decreto. }\end{array}$ \\
\hline Austrália & proibitiva & $\begin{array}{l}\text { Lei sobre proibição de clonagem } \\
\text { humana para reprodução e sobre a } \\
\text { regulação da pesquisa com } \\
\text { embriões humanos (2006)[lei que } \\
\text { traz alterações às leis anteriores, } \\
\text { de 2002] }\end{array}$ & $\begin{array}{l}\text { São proibidos: } \\
\text { (a) criar ou desenvolver intencionalmente um } \\
\text { embrião humano por meio de um processo que não } \\
\text { seja a fertilização de um óvulo humano por um } \\
\text { espermatozoide } \\
\text { (b) embriões humanos que contêm material } \\
\text { genético fornecido por mais de duas pessoas }\end{array}$ \\
\hline Áustria & proibitiva & $\begin{array}{l}\text { Lei sobre reprodução humana } \\
\text { medicamente assistida }(1992,2004)\end{array}$ & $\begin{array}{l}\text { Qualquer intervenção que envolva a linhagem } \\
\text { germinativa humana é proibida. }\end{array}$ \\
\hline Bélgica & proibitiva & $\begin{array}{l}\text { Lei sobre pesquisa com embriões in } \\
\text { vitro (2003) }\end{array}$ & $\begin{array}{l}\text { É proibido implantar embriões expostos a pesquisa } \\
\text { que afete a integridade do embrião em humanos. }\end{array}$ \\
\hline Brasil & proibitiva & Lei de Biossegurança (2005) & $\begin{array}{l}\text { É proibida engenharia genética em gametas } \\
\text { humanos, zigotos humanos ou embriões humanos. }\end{array}$ \\
\hline Bulgária & proibitiva & $\begin{array}{l}\text { Lei da saúde da Bulgária (SG n. } \\
70 / 10 \text { 2004) }\end{array}$ & $\begin{array}{l}\text { Uma intervenção com intuito de modificar o } \\
\text { genoma humano é permitida apenas com objetivos } \\
\text { preventivos ou terapêuticos e não com objetivos de }\end{array}$ \\
\hline
\end{tabular}




\begin{tabular}{|c|c|c|c|}
\hline & & & $\begin{array}{l}\text { introduzir uma modificação no genoma da } \\
\text { progenitura. }\end{array}$ \\
\hline Canadá & proibitiva & $\begin{array}{l}\text { Lei sobre reprodução humana } \\
\text { assistida (2004) }\end{array}$ & $\begin{array}{l}\text { É proibido alterar o genoma de uma célula de um } \\
\text { ser humano ou in vitro de forma que a alteração } \\
\text { seja capaz de ser transmitida a descendentes. }\end{array}$ \\
\hline Chile & ambígua & $\begin{array}{l}\text { Lei n. } 20.120 \text { sobre pesquisa com } \\
\text { humanos e seu genoma, e a } \\
\text { proibição da clonagem humana } \\
\text { (2006) }\end{array}$ & $\begin{array}{l}\text { Terapia genética em células somáticas pode ser } \\
\text { autorizada somente para tratamento de doença ou } \\
\text { para prevenir sua ocorrência. A posição sobre } \\
\text { modificação genética da linhagem germinativa } \\
\text { para reprodução é ambígua na lei. }\end{array}$ \\
\hline China & proibitiva & $\begin{array}{l}\text { Diretrizes sobre tecnologias de } \\
\text { reprodução humana assistida (2003) }\end{array}$ & $\begin{array}{l}\text { São proibidas a utilização de plasma de óvulo } \\
\text { humano e tecnologia de transferência nuclear com } \\
\text { objetivos reprodutivos e a manipulação de genes } \\
\text { em gametas, zigotos e embriões humanos com } \\
\text { objetivos reprodutivos. }\end{array}$ \\
\hline Colômbia & proibitiva & Código Penal (lei n. 599 de 2000) & $\begin{array}{l}\text { Embora a manipulação genética para prevenção e } \\
\text { tratamento de doenças genéticas, deficiências ou } \\
\text { influência genética seja permitida, a posição sobre } \\
\text { a modificação genética da linhagem germinativa } \\
\text { para reprodução é ambígua na lei. }\end{array}$ \\
\hline $\begin{array}{l}\text { Coreia do } \\
\text { Sul }\end{array}$ & proibitiva & Lei de bioética e segurança (2008) & $\begin{array}{l}\text { É proibida a terapia genética em esperma, oócitos, } \\
\text { embriões ou fetos. }\end{array}$ \\
\hline Costa Rica & proibitiva & $\begin{array}{l}\text { Decreto n. } 24029-S \text { - Regulação } \\
\text { sobre reprodução assistida (1995) }\end{array}$ & $\begin{array}{l}\text { São proibidas todas as formas de manipulação dos } \\
\text { códigos genéticos dos embriões assim como } \\
\text { experimentos com embriões. }\end{array}$ \\
\hline Dinamarca & proibitiva & $\begin{array}{l}\text { Lei sobre fertilização assistida } \\
\text { pertinente ao tratamento, diagnose e } \\
\text { pesquisa médicos (1997, alterada } \\
\text { em 2003) }\end{array}$ & $\begin{array}{l}\text { Implantar um óvulo humano fertilizado no útero de } \\
\text { uma mulher é proibido se o óvulo for } \\
\text { geneticamente alterado (modificado) e essa } \\
\text { alteração provavelmente danificou o óvulo em seu } \\
\text { ulterior desenvolvimento. }\end{array}$ \\
\hline Eslováquia & ambígua & $\begin{array}{l}\text { Lei da assistência médica n. } \\
\text { 277/1994 }\end{array}$ & $\begin{array}{l}\text { Embora pesquisa com desígnios médicos com } \\
\text { embriões e fetos humanos possa ser permitida, a } \\
\text { postura sobre modificação genética da linhagem } \\
\text { germinativa não é clara na lei. }\end{array}$ \\
\hline Espanha & proibitiva & $\begin{array}{l}\text { Lei } 14 / 2006 \text { sobre técnicas de } \\
\text { reprodução humana assistida }\end{array}$ & $\begin{array}{l}\text { São proibidas técnicas reprodutivas que não sejam } \\
\text { inseminação artificial, fertilização in vitro, injeção } \\
\text { intracitoplasmática de espermatozoides com } \\
\text { gametas próprios ou de doador, transferência de } \\
\text { embrião pré-implantacional e transferência } \\
\text { intrafalopiana de gameta. }\end{array}$ \\
\hline $\begin{array}{l}\text { Estados } \\
\text { Unidos da } \\
\text { América }\end{array}$ & proibitiva & $\begin{array}{l}\text { Diretrizes do Instituto Nacional de } \\
\text { Saúde para pesquisa que envolva } \\
\text { moléculas de ácido nucleico }\end{array}$ & $\begin{array}{l}\text { Atualmente propostas de ensaios clínicos para } \\
\text { alterações da linhagem germinativa não serão } \\
\text { aceitas pelo Comitê Consultivo de } \mathrm{ADN}\end{array}$ \\
\hline
\end{tabular}




\begin{tabular}{|c|c|c|c|}
\hline & & recombinantes ou sintéticas (2013) & $\begin{array}{l}\text { Recombinante (RAC) do Instituto Nacional de } \\
\text { Saúde (NIH). A FDA (Food and Drug } \\
\text { Administration) também regula o estudo clínico. }\end{array}$ \\
\hline Finlândia & proibitiva & $\begin{array}{l}\text { Lei sobre pesquisa médica } \\
(488 / 1999,295 / 2004,794 / 2010)\end{array}$ & $\begin{array}{l}\text { Pesquisa com embriões e gametas para modificar } \\
\text { propriedades genéticas é permitida se a pesquisa } \\
\text { objetiva curar ou prevenir uma doença hereditária } \\
\text { grave. Entretanto, os embriões que foram usados } \\
\text { para pesquisa não podem ser implantados em um } \\
\text { corpo humano. }\end{array}$ \\
\hline França & proibitiva & $\begin{array}{l}\text { Lei de bioética (2004, emendada em } \\
2009)\end{array}$ & $\begin{array}{l}\text { Produzir modificação nas características genéticas } \\
\text { com o objetivo de modificar a descendência de } \\
\text { uma pessoa é proibido, sem prejuízo quanto à } \\
\text { pesquisa para a prevenção e tratamento de doenças } \\
\text { genéticas. }\end{array}$ \\
\hline Grécia & ambígua & $\begin{array}{l}\text { Lei n. } 3305-\text { Aplicação da } \\
\text { reprodução medicamente assistida } \\
(2005)\end{array}$ & $\begin{array}{l}\text { A pesquisa embrionária pode ser permitida se o seu } \\
\text { objetivo for obter conhecimento importante e } \\
\text { relevante para a implantação bem sucedida de } \\
\text { óvulos fertilizados e para o nascimento de crianças } \\
\text { saudáveis. Entretanto, a posição sobre a } \\
\text { modificação genética da linhagem germinativa } \\
\text { para reprodução é ambígua na lei. }\end{array}$ \\
\hline Holanda & proibitiva & $\begin{array}{l}\text { Lei com regras relacionadas ao uso } \\
\text { de gametas e embriões (2002) }\end{array}$ & $\begin{array}{l}\text { A modificação deliberada do material genético do } \\
\text { núcleo de células de linhagem germinativa } \\
\text { humanas com as quais a gravidez pode ser iniciada, } \\
\text { é um ato proibido. }\end{array}$ \\
\hline Índia & proibitiva & $\begin{array}{l}\text { Diretrizes } \\
\text { éticas } \\
\text { biomédica } \\
\text { com }\end{array}$ & $\begin{array}{l}\text { Terapia de linhagem germinativa, terapia genética } \\
\text { para aprimoramento e engenharia genética } \\
\text { eugênica são proibidas. }\end{array}$ \\
\hline Irlanda & proibitiva & $\begin{array}{l}\text { Guia sobre conduta profissional e } \\
\text { ética para profissionais médicos, } \\
\text { sétima edição, 2009, Conselho de } \\
\text { Medicina }\end{array}$ & $\begin{array}{l}\text { Uma vez que criar embriões especificamente para } \\
\text { pesquisa é proibido, modificação genética da } \\
\text { linhagem germinativa para reprodução é também } \\
\text { interpretada como proibida. }\end{array}$ \\
\hline Islândia & ambígua & $\begin{array}{l}\text { Lei sobre fertilização artificial e uso } \\
\text { de gametas e embriões humanos } \\
\text { para pesquisa com células-tronco } \\
(55 / 1996)\end{array}$ & $\begin{array}{l}\text { Pesquisa, experimentos e procedimentos com } \\
\text { embriões de fertilização in vitro para melhorar o } \\
\text { entendimento sobre as causas das doenças } \\
\text { congênitas e abortos espontâneos podem ser } \\
\text { permitidos. Entretanto, a posição sobre a } \\
\text { modificação genética da linhagem germinativa } \\
\text { para reprodução é ambígua na lei. }\end{array}$ \\
\hline Israel & proibitiva & $\begin{array}{l}\text { Lei sobre proibição de intervenção } \\
\text { genética (clonagem humana e } \\
\text { manipulação genética de gametas) }\end{array}$ & $\begin{array}{l}\text { Usar células reprodutivas que passaram por } \\
\text { deliberada modificação genética permanente } \\
\text { (terapia genética de linhagem germinativa) para }\end{array}$ \\
\hline
\end{tabular}




\begin{tabular}{|c|c|c|c|}
\hline & & $\begin{array}{l}\text { (1999, renovada em 2004, 2009, e } \\
\text { válida até } 23 \text { de maio de 2016) }\end{array}$ & causar a criação de uma pessoa, é um ato proibido. \\
\hline Itália & proibitiva & $\begin{array}{l}\text { Lei sobre procriação medicamente } \\
\text { assistida (2004) }\end{array}$ & $\begin{array}{l}\text { Manipulação embrionária e modificação genética } \\
\text { com fins reprodutivos ou de pesquisa terapêutica } \\
\text { são proibidas. }\end{array}$ \\
\hline Japão & proibitiva & $\begin{array}{l}\text { Diretrizes sobre pesquisa clínica } \\
\text { relativa a terapia genética ( } 2002 \text {, } \\
\text { alterada em } 2004,2008)\end{array}$ & $\begin{array}{l}\text { É proibido pesquisa clínica que conduza } \\
\text { deliberadamente ou que possa conduzir à } \\
\text { modificação genética de células germinativas ou } \\
\text { embriões humanos. }\end{array}$ \\
\hline Lituânia & proibitiva & $\begin{array}{l}\text { Lei sobre ética da pesquisa } \\
\text { biomédica } \\
\text { alterada em 2007) }\end{array}$ & $\begin{array}{l}\text { O uso de embriões para pesquisa é restrito a } \\
\text { estudos não-interventivos. }\end{array}$ \\
\hline México & proibitiva & Lei geral de saúde (1997) & $\begin{array}{l}\text { Embora a reprodução assistida seja permitida, o } \\
\text { uso de tecidos embrionários ou de tecidos fetais } \\
\text { para pesquisa é proibido e interpretado como } \\
\text { vedado com relação à modificação genética da } \\
\text { linhagem germinativa. }\end{array}$ \\
\hline $\begin{array}{l}\text { Nova } \\
\text { Zelândia }\end{array}$ & proibitiva & $\begin{array}{l}\text { Lei sobre tecnologia de reprodução } \\
\text { humana assistida (2004) }\end{array}$ & $\begin{array}{l}\text { É proibido implantar em um ser humano um } \\
\text { gameta, um embrião humano ou um embrião } \\
\text { híbrido que tenham sido geneticamente } \\
\text { modificados. }\end{array}$ \\
\hline Peru & ambígua & Lei geral de saúde $(26842 / 1997)$ & $\begin{array}{l}\text { Embora seja proibida a fertilização de oócitos } \\
\text { humanos com fins outros que não a procriação, a } \\
\text { posição sobre a modificação genética da linhagem } \\
\text { germinativa é ambígua na lei. }\end{array}$ \\
\hline Portugual & proibitiva & $\begin{array}{l}\text { Lei sobre procriação medicamente } \\
\text { assistida }(32 / 2006)\end{array}$ & $\begin{array}{l}\text { A modificação genética da linhagem germinativa } \\
\text { para reprodução é proibida, pois a criação de } \\
\text { embriões humanos para pesquisa é proibida. }\end{array}$ \\
\hline Reino Unido & proibitiva & $\begin{array}{l}\text { Lei sobre fertilização humana e } \\
\text { embriologia (1990, alterada em } \\
\text { 2008)-Regulações sobre } \\
\text { fertilização humana e embriologia } \\
\text { (fins de pesquisa) (2001) }\end{array}$ & 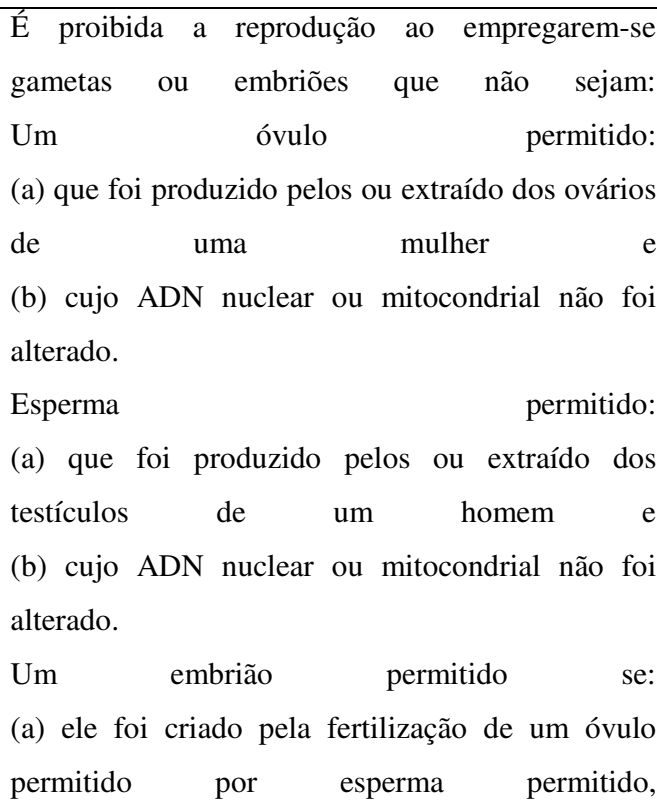 \\
\hline
\end{tabular}




\begin{tabular}{|c|c|c|c|}
\hline & & & $\begin{array}{l}\text { (b) nenhum ADN nuclear ou mitocondrial de } \\
\text { célula alguma do embrião foi alterado e } \\
\text { (c) nenhuma célula tenha sido acrescentada a ele } \\
\text { por outro meio que não a divisão das células do } \\
\text { próprio embrião. }\end{array}$ \\
\hline $\begin{array}{l}\text { República } \\
\text { Tcheca }\end{array}$ & proibitiva & $\begin{array}{l}\text { Convenção para a proteção dos } \\
\text { direitos humanos e da dignidade } \\
\text { humana concernente à aplicação da } \\
\text { biologia e da medicina: Convenção } \\
\text { sobre diretos humanos e } \\
\text { biomedicina }(96 / 2001) \cdot \text { Lei sobre } \\
\text { pesquisa com células-tronco } \\
\text { embrionárias e atividades } \\
\text { relacionadas, e que traz alterações a } \\
\text { algumas leis relacionadas (2006) }\end{array}$ & $\begin{array}{l}\text { Uma intervenção que pretenda modificar o genoma } \\
\text { humano é permitida apenas se tiver fins } \\
\text { preventivos, diagnósticos ou terapêuticos e } \\
\text { somente se seu objetivo não for modificação } \\
\text { alguma no genoma de descendente algum. A lei } \\
\text { permite o uso de embriões em pesquisa apenas para } \\
\text { a instituição de células-tronco embrionárias. }\end{array}$ \\
\hline Rússia & ambígua & $\begin{array}{l}\text { Lei sobre a regulação estatal no } \\
\text { âmbito das atividades de engenharia } \\
\text { genética(1996, alterada em 2000, } \\
\text { 2008, 2010) • Lei de proteção à } \\
\text { saúde dos cidadãos da Federação } \\
\text { Russa (22.07.1993.Reg. No5487- } \\
\text { I) Ordem } 67 \text { do Ministério da } \\
\text { Saúde da Federação Russa (Reg. } \\
\text { No4452 24.04.03) }\end{array}$ & $\begin{array}{l}\text { É necessário um profissional médico de terapia } \\
\text { genética somática para se obter uma autorização } \\
\text { federal. Além disso, tecnologias de reprodução } \\
\text { assistida que são estipuladas pela ordem } 67 \text { são } \\
\text { permitidas em estabelecimentos licenciados. A } \\
\text { pesquisa embrionária é legal. Entretanto, a } \\
\text { modificação genética da linhagem germinativa } \\
\text { para reprodução não é tratada pela legislação nem } \\
\text { pela ordem } 67 \text {. }\end{array}$ \\
\hline Singapura & proibitiva & $\begin{array}{l}\text { Lei sobre clonagem humana e } \\
\text { outras práticas proibidas (2004) }\end{array}$ & $\begin{array}{l}\text { É proibido desenvolver embriões humanos criados } \\
\text { por meio que não seja a fertilização de um óvulo } \\
\text { humano com esperma humano. }\end{array}$ \\
\hline Suécia & proibitiva & Lei da integridade genética (2006) & $\begin{array}{l}\text { São proibidos experimentos com objetivos de } \\
\text { pesquisa ou tratamento que ocasionam alterações } \\
\text { genéticas que podem ser herdadas por humanos. }\end{array}$ \\
\hline Suíça & proibitiva & Constituição Federal (1999) & $\begin{array}{l}\text { São proibidas todas as formas de clonagem e de } \\
\text { interferência com o material genético de células } \\
\text { reprodutivas e embriões humanos. }\end{array}$ \\
\hline
\end{tabular}

* Os países listados foram pesquisados com foco na política sobre modificação genética da linhagem germinativa excluindo-se a clonagem reprodutiva em 1 de abril de 2014.

* A pesquisa é baseada em proposições de legislação ou diretrizes relacionadas, mas inclui paráfrases e interpretação.

* A modificação genética da linhagem germinativa foi interpretada como proibida em países que vedam a pesquisa com embriões humanos, porque pesquisa pré-clínica e estudos clínicos relevantes restam impossíveis.

Fonte: ARAKI; ISHII, 2014.

Como é possível observar, na maioria dos países são proibidas ou limitadas, mediante legislação e diretrizes específicas, pesquisas científicas que possam realizar ingerências na genética humana. Todavia, a legislação brasileira é deficiente no tratamento normativo das 
questões relacionadas aos avanços biotecnológicos, mormente no que diz respeito à incidência em seres humanos. A Lei de Biossegurança (Lei 11.105, de 24 de março de 2005), prevê tão somente um artigo para tratar de tema tão relevante e complexo e, embora já tenha se passado uma década da referida lei e o desenvolvimento científico seja cada vez mais acelerado e abrangente, não sobreveio outra normatização acerca da matéria. Ademais, a mencionada lei foi criada para regular o uso de sementes transgênicas na agricultura, tema com forte conotação política e econômica. A inserção do dispositivo relativo à utilização de célulastronco embrionárias é notoriamente desconexa com o teor da referida lei, sem a respectiva descrição no preâmbulo e carente de discussão prévia (GOLDIM, 2014). Diante deste contexto, denotam-se dois importantes aspectos: o primeiro, no que diz respeito à deficiência do sistema normativo brasileiro diante de questões tão relevantes e, o segundo, no sentido de que o inexorável e crescente avanço da tecnociência, requer reflexões e providências normativas prementes acerca do assunto.

No julgamento da Ação Direta de Inconstitucionalidade (ADI 3510, 2008), que tratou da arguição de inconstitucionalidade do indigitado artigo $5^{\circ}$ da Lei de Biossegurança, o Ministro Gilmar Mendes acentua que causa perplexidade notar que no Brasil "a regulamentação de um tema tão sério, que envolve profundas e infindáveis discussões sobre aspectos éticos nas pesquisas científicas, seja realizada por um, e apenas um artigo." Deste modo, na esteira da doutrina e do entendimento jurisprudencial consolidado na Corte Constitucional alemã, o Ministro observa que a deficiência da legislação brasileira viola o princípio da proporcionalidade, na medida em que para efetivação dos direitos fundamentais, o Estado tem o dever não apenas de se abster de intervir no âmbito de proteção dos direitos individuais, mas também de protegê-los contra agressões propriciadas por terceiros. Em suma, o Estado tem o dever de proibição, no sentido de proibir determinadas condutas, o dever de segurança, para proteger os indivíduos contra ataques de terceiros, e o dever de evitar riscos, mediante medidas de proteção ou prevenção, especialmente em relação ao desenvolvimento tecnológico.

No Brasil, na ausência de legislação específica sobre pesquisa em seres humanos e reprodução humana assistida, as diretrizes orientadoras são as Resoluções do Conselho Nacional de Saúde (CNS), para a pesquisa em seres humanos, e do Conselho Federal de Medicina (CFM), para a reprodução assistida. A Resolução CNS n ${ }^{\circ} 466$, de 12 de dezembro de 2012 não tem qualquer referência específica à questão da pesquisa em embriões, salvo a 
necessidade de que sejam avaliados pelo Comitê de Ética em Pesquisa (CEP) e pela Comissão Nacional de Ética em Pesquisa (CONEP). Por outro lado, a recente Resolução CFM n ${ }^{\circ} 2121$, de 24 de setembro de 2015, permite que nos procedimentos de reprodução assistida, “embriões submetidos a diagnóstico de alterações genéticas causadoras de doenças" podem ser doados para pesquisa. A mesma Resolução estabelece que o tempo máximo de desenvolvimento de embriões in vitro é de 14 dias. Anteriormente, a Lei de Biossegurança (2005) já havia aberto a possibilidade de que embriões congelados em 2005, ou que já tivessem o prazo de três anos, quando da aprovação da lei, em março de 2005, pudessem ser doados à pesquisa.

Enfim, é preciso desconstruir paradigmas existentes com relação às novas tecnologias, assim como construir parâmetros éticos e jurídicos para controlar o desenvolvimento, a implementação e o uso das ferramentas de intervenção genética. Para desempenhar tão importante tarefa, é importante que sejam observados diferentes referenciais teóricos, conforme indica o Modelo da Bioética Complexa, tais como os princípios bioéticos, os direitos humanos, as virtudes, a alteridade, a responsabilidade e a experiência oriunda dos casos paradigmáticos. A interface entre disciplinas e áreas de conhecimento possibilita uma visão mais significativa e abrangente do tema (GENRO; FRANCESCONI; GOLDIM, 2014). A Bioética pode ser assim entendida como "uma reflexão complexa, interdisciplinar e compartilhada sobre a adequação das ações envolvendo a vida e o viver" (GOLDIM, 2009, p. 59).

Existe ainda uma complementaridade necessária entre a Bioética e o Biodireito, a mesma que ocorre entre a Ética e o Direito (BARRETTO, 2013). O Biodireito, que tem como objeto principal a vida e como fonte imediata a Bioética, compreende um conjunto de normas jurídicas e de decisões judiciais que buscam regular a conduta humana em face dos avanços da biotecnologia. Assim, a Bioética poderá construir o suporte ético, fornecendo elementos, subsídios, instrumentos e orientações para o equacionamento e a formulação de normas jurídicas, assim como a deliberação frente aos problemas decorrentes das biotecnologias (BARBOZA, 2009).

Os contornos de uma Bioética e de um Biodireito representativos nas sociedades contemporâneas são formados pela legitimidade da esperança no progresso tecnocientífico, do exercício da liberdade e da importância da noção de responsabilidade diante das novas tecnologias (MÖLLER, 2009). É preciso refletir acerca dos instrumentos oferecidos para 
normatizar as novas conquistas científicas, observando que a tendencial estabilidade das normas jurídicas nem sempre é compatível com a incerteza da pesquisa científica. Enfim, é necessária uma observação e análise crítica, atentando-se à linguagem jurídica e seus institutos, adaptados ou reformulados de acordo com as reflexões bioéticas (MARTINSCOSTA, 2009).

Com base nos aspectos mencionados, denota-se a importância da construção de diretrizes no sentido de recomendar, permitir, obrigar, desencorajar e/ou proibir técnicas de interferência genética, de acordo com o potencial de abrangência das tecnologias. A relevância das questões relacionadas às intervenções na vida e na saúde humana requerem reflexões no âmbito da sociedade civil, das instituições de ensino e de pesquisa, de entidades médicas e hospitalares, de conselhos profissionais, de conselhos de ética, de comissões nacionais, de comitês de bioética, do legislativo, do executivo e do judiciário, dos organismos internacionais, etc. Enfim, tratam-se de questões de importância fundamental que requerem a atenção da sociedade e do Estado.

\section{Considerações finais}

A medicina genética corretiva torna cada vez maiores as possibilidades de prevenir e de curar doenças, assim como de modelar características biológicas em seres humanos. Todavia, as intervenções genéticas favorecem, a um só tempo, perspectivas e incertezas, na medida em que não conhecemos os limites das respectivas mutações. Deparamo-nos, portanto, com o seguinte antagonismo: por um lado, a implementação de novas tecnologias de edição genética provoca expectativas de significativos benefícios para a vida e para a saúde e, por outro, desencadeia preocupações com relação aos riscos que permeiam a interferência no genoma humano.

O histórico das técnicas de edição do DNA se confunde com a própria evolução da discussão dos aspectos bioéticos associados à pesquisa científica. As crescentes pesquisas e o interesse pelo CRISPR-Cas9 são acompanhados por indagações e preocupações acerca de sua implementação. Estão sendo encaminhadas inúmeras propostas de criação de fóruns de discussão específicos com relação ao tema e amplos em termos de representatividade. Um grupo de cientistas, liderado novamente por David Baltimore (Prêmio Nobel em 1975) e Paul 
Berg (Prêmio Nobel em 1980), publicou, em abril de 2015, uma nova carta na revista Science, apresentando propostas de reflexão sobre a utilização do sistema.

O debate está aberto e a lição da Conferência de Asilomar ainda é útil e adequada. Não se trata de banir as pesquisas ou impedir o uso do método de intervenção genética, mas de promover reflexões para verificar sua adequação às diferentes pesquisas que estão sendo propostas. Estabelecer uma moratória para os respectivos experimentos é uma alternativa prudente para que sejam estabelecidos critérios mínimos e comuns de adequação. As respectivas diretrizes requerem implementação internacional, de modo a evitar que pesquisas possam ser direcionadas para serem realizadas em países com menor rigor de avaliação ética.

Neste processo, é relevante que sejam considerados diferentes referenciais teóricos, conforme indica o Modelo da Bioética Complexa, tais como os princípios bioéticos, os direitos humanos, as virtudes, a alteridade, a responsabilidade e a experiência oriunda dos casos paradigmáticos para tratar das questões decorrentes das tecnologias de intervenção genética. Afora os mencionados referenciais, há uma complementaridade necessária entre a Bioética e o Biodireito para o relevante papel de perquirir, analisar, desconstruir paradigmas e definir diretrizes éticas e jurídicas para nortear o inexorável e crescente desenvolvimento científico e tecnológico.

Assinalamos, portanto, a importância da reflexão e da construção de estruturas de orientação no que diz respeito às técnicas de intervenção genética, de modo a promover maior segurança aos avanços tecnocientíficos e à humanidade. Do contrário, torna-se iminente o risco de transformar-se em realidade o hipotético “Admirável Mundo Novo" imaginado por Aldous Huxley há quase um século, ou até mesmo outras ficções científicas que delineiam expectativas e temores com relação ao assunto. Na realidade o que almejamos é viver num mundo em que ocorra o equilíbrio entre o desenvolvimento e a responsabilidade, isto é, que a ciência e a técnica estejam em harmonia com a vida e a saúde humana.

\title{
GENETIC INTERVENTIONS IN HUMANS: ETHICAL AND LEGAL ASPECTS
}

\begin{abstract}
Advances in biotechnology may generate increasing and significant changes in human life and health. Despite the significant benefits wich come from the use of technics, the inherent risks and the lack of knowledge of limits are causes for concerns and disagreements, especially with regard to genetic interventions. A recent example is the use of CRISPR-Cas9 (Clustered Regularly Interspaced Short Palindromic Repeats, associated with protein 9)
\end{abstract}


system to introduce specific mutations in human genome. This article aims to inquire into ethical and legal aspects that permeate the corrective genetic medicine. In order to develop the proposed objective, the qualitative method of approach is used with documentary research on the subject. As result, it was found the importance of (de)construction of parameters to guide the development and implementation of techniques of intervention in human genetics, so that greater security is promoted to research and to mankind.

Keywords: CRISPR-Cas Systems. Bioethics. Law.

\section{INTERVENCIONES GENÉTICAS EN SERES HUMANOS: ASPECTOS ÉTICOS Y JURÍDICOS}

\section{Resumen}

Los avances d la biotecnología pueden generar crecientes y significativas transformaciones en la vida y en la salud de seres humanos. En que pese a los relevantes beneficios que advienen del uso de las respectivas técnicas, los riesgos inherentes y el desconocimiento de límites son motivos de inquietudes y divergencias, especialmente en lo que se refiere a las intervenciones genéticas. Ejemplo reciente es el uso del sistema CRISPR-Cas9 (Clustered Regularly Interspaced Short Palindromic Repeats - Cas9 associated) para introducir mutaciones específicas en el genoma humano. El presente artículo tiene como ámbito abarcar aspectos éticos y jurídicos que permean la medicina genética correctiva. Para desarrollar el objetivo propuesto, utilizamos el método cualitativo de abordaje, mediante investigación documental sobre el asunto. Como resultado, verificamos la importancia de la (des)construcción de parámetros para guiar el desarrollar y la implementación de las técnicas de intervención en la genética humana, de modo a promover más seguridad a la investigación y a la humanidad.

Palabras Clave: Sistemas CRISPR-Cas. Bioética. Derecho.

\section{REFERÊNCIAS}

ANDORNO, Roberto. "Liberdade" e "Dignidade" da pessoa: dois paradigmas opostos ou complementares na bioética? In: MARTINS-COSTA, Judith; MÖLLER, Letícia Ludwig (Org.). Bioética e Responsabilidade. Rio de Janeiro: Forense, 2009, p. 73-93.

ARAKI, Motoko; ISHII, Tetsuya. (2014) International regulatory landscape and integration of corrective genome editing into in vitro fertilization. Reproductive Biology and Endocrinology 12:108.

BALDO, Guilherme. Seminários Científicos: Centro de Pesquisa Experimental. O sistema CRISPR-Cas9: nova revolução na pesquisa biológica? Porto Alegre: HCPA/UFRGS. 18 ago. 2015.

BARRETTO, Vicente de Paulo. O fetiche dos direitos humanos e outros temas. 2. ed. Porto Alegre: Livraria do Advogado, 2013. 
BIBLIOTECA VIRTUAL: Fonte referencial de informação para a Pesquisa Apoiada pela FAPESP <http://www.bv.fapespbr/pt/pesquisa/?q=Crispr\&index=\&link_curto=.> Acesso em: 17 out. 2015.

BRASIL. Lei 11.105, de 24 de março de 2005. Regulamenta os incisos II, IV e V do § 1º do art. 225 da Constituição Federal, estabelece normas de segurança e mecanismos de fiscalização de atividades que envolvam organismos geneticamente modificados - OGM e seus derivados, cria o Conselho Nacional de Biossegurança - CNBS, reestrutura a Comissão Técnica Nacional de Biossegurança - CTNBio, dispõe sobre a Política Nacional de Biossegurança - PNB, revoga a Lei no 8.974, de 5 de janeiro de 1995, e a Medida Provisória $\mathrm{n}^{\mathrm{o}} 2.191-9$, de 23 de agosto de 2001 , e os arts. $5^{\circ}, 6^{\circ}, 7^{\circ}, 8^{\circ}, 9^{\circ}, 10$ e 16 da Lei $\mathrm{n}^{\mathrm{o}} 10.814$, de 15 de dezembro de 2003, e dá outras providências. Disponível em:

<http://www.planalto.gov.br/ccivil_03/_ato2004-2006/2005/lei/111105.htm>. Acesso em: 15 out. 2015.

BRASIL. Supremo Tribunal Federal. Ação Direta de Inconstitucionalidade $n^{\circ} 3.510$ Distrito Federal. Requerente: Procurador-Geral da República. Requerido: Presidente da República, Congresso Nacional. Relator: Ministro Ayres Britto. Brasília, DF, 29 de maio de 2008. Disponível em:

$<$ http://redir.stf.jus.br/paginadorpub/paginador.jsp?docTP=AC\&docID=611723>. Acesso em: 29 set. 2015.

BUCHANAN, Allen; BROCK, Dan W; DANIELS, Norman; WIKLER, Daniel. From Chance to Choice: Genetics and Justice. Cambridge: Cambridge University Press, 2000.

CARVALHO, Talita G.; MATTE, Úrsula da S.; GIUGLIANI, Roberto; BALDO, Guilherme. (2015) Genome Editing: Potential Treatment for Lysosomal Storage Diseases. Curr Stem Cell Rep 1:9-15.

CONSELHO FEDERAL DE MEDICINA - CFM. Resolução CFM n²121, de 24 de setembro de 2015. Adota as normas éticas para utilização das técnicas de reprodução assistida - sempre em defesa do aperfeiçoamento das práticas e da observância aos princípios éticos e bioéticos que ajudarão a trazer maior segurança e eficácia a tratamentos e procedimentos médicos - tornando-se o dispositivo deontológico a ser seguido pelos médicos brasileiros e revogando a Resolução CFM n ${ }^{\circ}$ 2.013/13, publicada no DOU de 9 de maio de 2013. Disponível em: <http://www.portalmedico.org.br/resolucoes/CFM/2015/2121_2015.pdf> Acesso em: 10 nov. 2015.

CONSELHO NACIONAL DE SAÚDE - CNS. Resolução CNS $n^{\circ}$ 466, de 12 de dezembro de 2012. Estabelece diretrizes e normas regulamentadoras de pesquisas envolvendo seres humanos. Disponível em: < http://conselho.saude.gov.br/resolucoes/2012/Reso466.pdf> Acesso em: 10 nov. 2015.

CORTINA, Adela; MARTÍNEZ, Emilio. Ética. Trad. Silvana Cobucci Leite. 2. ed. São Paulo: Loyola, 2009.

CRESSEY, Daniel; ABBOTT, Alison; LEDFORD, Heidi (2015). UK scientists apply for licence to edit genes in human embryos. Nature News, 18 set. 2015.

CRESSEY, Daniel (2013). Dna's Master Editor. Nature 358: 19-26. 
DELMAS-MARTY, Mireille. O universalismo dos direitos humanos em questão - o exemplo do direito à vida. In: TEIXEIRA, Anderson V., OLIVEIRA, Elton Somensi de (Org.).

Correntes contemporâneas do pensamento jurídico. Barueri: Manole, 2009.

FOUCAULT, Michel. Em defesa da sociedade. São Paulo: Martins Fontes, 2002. p. 286-290.

GENRO, Bruna Pasqualini; FRANCESCONI, Carlos Fernando Magalhães; GOLDIM, José Roberto. Bioética Clínica: vinte anos de experiência no Hospital de Clínicas de Porto Alegre. Revista da AMRIGS, Porto Alegre: AMRIGS, v. 58, p. 83-88, 2014.

GOLDIM, José Roberto. Genetics and ethics: a possible and necessary dialogue. Journal of Community Genetics, p. epub ahead, 2015.

. Bioética complexa: uma abordagem abrangente para o processo de tomada de decisão.

In: Revista da AMRIGS, Porto Alegre: AMRIGS, v. 53, p. 58-63, 2009.

. Bioética, Biopolítica e Biopoder. Zero Hora, Porto Alegre, p. 26, 23 out. 2014.

. Conferência de Asilomar. Disponível em: <http://www.ufrgs.br/bioetica/asilomar.htm> Acesso em: 14 out. 2015. Texto postado no Portal de Bioética da UFRGS.

GRENS, Kerry (2015). There's CRISPR in Your Yogurt: We've all been eating food enhanced by the genome-editing tool for years. The Scientist. Disponível em: http://www.thescientist.com/?articles.view/articleNo/41676/title/There-s-CRISPR-in-Your-Yogurt/> Acesso em: 9 ago. 2015.

HABERMAS, Jürgen. O futuro da natureza humana: a caminho de uma eugenia liberal? Trad. Karina Janinni. São Paulo: Martins Fontes, 2004.

HONNEFELDER, Ludger. Perspectivas da tecnologia genética: um desafio para a ética. In: SOUZA, Draiton Gonzaga; ERDTMANN, Bernardo (org). Ética e genética II. Porto Alegre: EDIPUCRS, 2003. P. 15-29.

HUXLEY, Aldous Leonard. Admirável Mundo Novo. Trad. Vidal de Oliveira e Lino Vallandro. 5. ed. Porto Alegre: Globo, 1979.

JONAS, Hans. O princípio responsabilidade: ensaio de uma ética para a civilização tecnológica. Trad. Luiz Barros Montes, Marijane Lisboa. Rio de Janeiro: Contraponto, 2006.

JUNGES, José Roque. O nascimento da Bioética e a constituição do biopoder. Acta Bioethica (Impresa), v. 17, p. 171-178, 2011.KANT, Immanuel. Fundamentação da metafísica dos costumes. Trad. nova com introdução de notas por Guido Antônio de Almeida. São Paulo: Discurso Editorial: Barcarolla, 2009.

LAUXEN, Elis Cristina Uhry. Perspectivas ético-jurídicas do marco inicial da vida humana no contexto dos avanços biotecnológicos. 2014. 140 f. Dissertação (Mestrado em Direito) Programa de Pós-Graduação em Direito, Universidade do Vale do Rio dos Sinos - UNISINOS, São Leopoldo, 2014. 
LIANG, Puping; et al. (2015) CRISPR/Cas9-mediated gene editing in human tripronuclear zygotes. Protein \& Cell; V 6, Issue 5, 363-372.

MARTINS-COSTA, Judith (Org.); MÖELLER, Letícia Ludwig (Org.). Bioética e Responsabilidade. Rio de Janeiro: Forense, 2009.

NAU J-I (2014) L'affaire «Crispr-Cas9» ou l' hummanité génétiquement dépassée. Rev. Med. Suisse. $10: 1428^{\mathrm{a}}-1419^{\mathrm{a}}$.

NIU Y., et al. (2014). Generation of gene-modified cynomolgus monkey via Cas9/RNAmediated gene targeting in one-cell embryos. Cell 156:836-843.

RESTA, Giorgio. O acesso ao material biológico humano com fins de pesquisa e de aproveitamento industrial: questões relativas ao consentimento e à responsabilidade na perspectiva do direito comparado. In: MARTINS-COSTA, Judith; MÖLLER, Letícia Ludwig (Org.). Bioética e Responsabilidade. Rio de Janeiro: Forense, 2009. p. 145-204.

RESULTADO FINAL PROBITI/FAPERGS 2015-2016

$<$ http://www.pucrs.br/research/documentos/resultadoPreliminarPROBITI2015-2016.pdf. Acesso em: 17 out. 2015.

SANDEL, Michael J. Contra a perfeição: ética na era da engenharia genética. Trad. Ana Carolina Mesquita. Rio de Janeiro Civilização Brasileira, 2013.

SAVULESCU J.; BOSTROM N. Human Enhancement. Oxford: OUP, 2010.

SCHAUER F. Slippery slopes. Harvard Law Rewiew. 1985;99:361-83.

SEN, Amartya; KLIKSBERG. As pessoas em primeiro lugar: a ética do desenvolvimento e os problemas do mundo globalizado. Trad. Bernardo Ajzemberg, Carlos Eduardo Lins da Silva. São Paulo: Companhia das Letras, 2010.

WEBBER, P. (2014). Does CRISPR-Cas open new possibilities for patents or presente a moral maze? Nature Biotechnology 32:331-333.

YIN, Hao; et al. (2014). Genome editing with Cas9 in adult mice corrects a disease mutation and phenotype. Nature Biotecnhnology 32: 551-553.

ZHANG, Sarah. Tudo o que você precisa saber sobre a CRISPR, nova ferramenta de edição de DNA. Disponível em: http://gizmodo.uol.com.br/tudo-o-que-cove-precisa-saber-sobre-acrispr-nova-ferramenta-de-ediçcao-de-dna > Acesso em: 14 out. 2015.

Data de recebimento: $14 / 12 / 15$

Data de aceite: $27 / 07 / 16$

\section{Sobre os autores:}

Elis Cristina Uhry Lauxen é Mestre em Direito pela UNISINOS. Pesquisadora do Laboratório de Pesquisa em Bioética e Ética na Ciência do Hospital de Clínicas de Porto Alegre LAPEBEC/HCPA. Endereço eletrônico: eclauxen@ gmail.com. 
José Roberto Goldim é Doutor em Medicina pela UFRGS. Professor da PUCRS e da UFRGS. Coordenador do LAPEBEC/HCPA e Chefe do Serviço de Bioética/HCPA. Endereço eletrônico: jrgoldim@gmail.com. 